\title{
INFORMATION SYSTEMS OUTSOURCING REASONS AND RISKS: REVIEW AND EVOLUTION
}

\begin{abstract}
The present paper proposes a set of outsourcing reasons and risks, subsequently assessing them in the case of major Spanish companies through a survey that was replicated twice. In order to achieve these aims, a questionnaire was administered to the IS managers of the largest Spanish firms. The longitudinal analysis allows us not only to draw trends but also to evaluate the degree of continuity and change in outsourcing reasons and risks. Even though the reasons seem to have remained fairly stable over time, the risks have changed with regard to their assessment during the last few years. In any case, the set of reasons and risks proposed should be taken into account by the management prior to making any outsourcing decision.
\end{abstract}

Keywords: Information Systems, Information Technologies, Outsourcing, Reasons, Risks, Longitudinal, Survey, Review, Evolution, Spain.

\section{INTRODUCTION}

Information Systems (IS) outsourcing has been consolidated as a usual practice among today's companies, regardless of their size, the importance that Information Technologies (IT) have for the business, and the own resources which those companies dedicate to computer departments (Ang and Cummings, 1997; Hurst and Hanessian, 1995). For this reason, the data provided by analysts and consultants on a national and international level confirm that IS outsourcing is a worldwide trend. Thus, according to the study carried out by KPMG (2013), the IT market showed a 3.5\% worldwide growth in 2013 -and is expected to have a $4.7 \%$ growth during the period 2013-2017. The same source referred to an IT service market worth 649 billion dollars in 2013. In the European case, the forecast for the total outsourcing market during 2013 was 204 billion dollars. After analyzing the 
reports written by several analysts in the field of IT services, Kotlarsky and Willcocks (2012) calculated that IT services will have grown by 5 to $8 \%$ per year between 2012 and 2016. The most recent reports forecasted that IT outsourcing would grow even after the financial crisis (Jain and Natarajan, 2011).

As companies are so prone to outsource all or part of the IT-related functions it is important to analyze and understand the reasons and motivations why companies resort to outsourcing -as well as to identify the risks which this management practice may entail. Our paper therefore has as its aim to analyze IS outsourcing reasons and risks, to propose a set of those reasons and risks, and to contrast their validity over time -providing a longitudinal vision. With that aim in mind, and in addition to making a review of the literature dedicated to the aforesaid reasons and risks, this research work presents the results of a survey which has been replicated for the second time among the largest Spanish companies -showing a 12-year evolution.

\section{LITERATURE REVIEW AND PROPOSAL}

\subsection{Outsourcing reasons}

\section{INSERT TABLE 1}

Numerous authors have already reflected on the main reasons leading to IS Outsourcing. Table 1 allows us to see a brief review of the literature which has dealt with outsourcing reasons, indicating both the authors and the arguments underlying those reasons. Our proposal for outsourcing reasons, which will be subsequently assessed during the empirical work stage, stems from the previous works by Gonzalez, Gasco and Llopis (2005a, 2010) and is succinctly explained below:

a) Focusing on Strategic Issues. The IS department can outsource non-strategic functions and places the emphasis on those which represent a competitive advantage (Lacity and Hirschheim, 1993a). The relationship with a more simplified IS department becomes 
easier (Grover, Cheon and Teng 1994) and it is possible for the company to focus on its basic competences (Willcocks, Feeny and Olson, 2006).

b) Increasing IS Department Flexibility. Companies can use outsourcing as a way to achieve flexibility within a reorganization or restructuring process (Yang, Kim, Nam, and Min (2007), or while generally redesigning its contracts in order to meet their business needs (Harland, Knight, Lamming and Walker, 2005).

c) Improving Quality. Outsourcing provides a possibility to improve IS service quality because the provider's technical and human resources complement those of the client. (Baldwing, Irani and Love, 2001; Al-Gharbi, Al-Kindi and Al-Salti, 2009; Alner, 2001).

d) Getting rid of Routine Tasks. Many of the tasks performed by the IS department are routine ones; they add no value and can be managed by any provider -since they do not constitute a differentiated service (Grover, Cheong and Teng, 1994, 1996, Hayes, Hunton and Reck, 2000).

e) Facilitating Access to Technology. Outsourcing gives access to technology which is offered by the provider (Lacity, Hirschheim and Willcocks, 1994). It also offers the possibility to experiment with new technologies supplied by the provider, thus minimizing risks when the client does not dare to invest in such technologies (Baldwing, Irani and Love, 2001).

f) Reducing the Risk of Obsolescence. Since the provider makes more investments in technology than the client, it is the former that assumes the risk of technological obsolescence in relation to equipment (Clark, Zmud and McCray, 1995; Grover, Cheon and Teng, 1994, 1996).

g) Saving Staff Costs. The provider company is in a better position not only to hire but also to motivate and train IS and IT specialists (Alner, 2001; Ang and Straub, 1998; Cox, Roberts and Walton, 2011), since that is precisely its business. 
h) Saving Technology Costs. Service providers achieve economies of scale and scope both when it comes to purchasing IT components and when it comes to managing them, and these savings can be enjoyed by the client too -as the latter has a lower service acquisition process that if it managed that service internally (Smith, Mitra and Narashiman, 1998). Outsourcing additionally turns fixed costs (those corresponding to own equipment) into variable ones (payments for the service received) which can be predictable costs if the contract is clearly structured (Cox, Roberts and Walton, 2011). Both aspects lead to savings in technological costs.

i) Having Alternatives to the internal IS. The client company has access to internal and external IT resources -technological as well as human ones. This can imply a continuity of the service, which represents a basic security measure for IS applications (Alner, 2001).

j) Joining the Fashion. Client companies copy or imitate the example of other organizations who have been successful with outsourcing, pushed by the economic press, and also by the pressure coming from providers themselves (Yang, Kim, Nam and Min (2007).

\subsection{Outsourcing Risks}

\section{INSERT TABLE 2}

The risks involved in IS outsourcing have been analyzed by many authors too. Table 2 contains a review of the literature about this topic -also complemented with an explanation of the arguments justifying such risks. This paper follows the studies carried out by Gonzalez, Gasco and Llopis $(2005 b, 2010)$ in order to suggest the most important risks involved in IS outsourcing, which are described below and will be subject to assessment during the empirical work stage: 
a) Qualification of the Provider's Staff. Lacity and Hirschheim (1993b) warned that, once they have achieved a contract, many providers send their best employees in search of new clients, which is why clients often complain about the deficient qualification of the provider's staff (Ngwenyama and Sullivan, 2007).

b) Excessive Dependence. A large number of clients end up being excessively dependent on the provider; they feel trapped and unable to leave their relationship with that provider (Bahli and Rivard, 2002, 2005).

c) Lack of Compliance. This risk is inherent in any contract because the client always faces the risk that the provider might not perform the tasks as expected (Clark, Zmud and McCray, 1995; Gandhi, Gorod and Sauser, 2012).

d) Loss of knowledge. The client gradually decapitalizes its IS department; its decision to outsource entails neglecting internal improvements, the training of its own IS staff and, very often, no transfer of knowledge and ideas exists between the provider and the client (Sullivan and Ngwenyama, 2005; Willcocks, Lacity and Kern, 1999, Verwaal, Verdu and Recter, 2008).

e) Provider's inability to adapt to technology. If the provider is not strong enough, it may neglect the improvements of its own technology and show reluctance to innovate until it has obtained a return on its mature technologies (Grover and Teng, 1993, Willcocks, Lacity and Kern, 1999).

f) Hidden Costs. Barthélemy (2001) uses this expression to define those costs which do not appear explicitly in the IT outsourcing contract but which will inevitable arise throughout the contract's validity period. Examples include: costs involved in looking for the right provider, transition costs, or costs associated with client-provider coordination and control (Bahli and Rivard, 2002; Fan, Suo and Feng, 2012; Palvia, 1995). 
g) Security Problems. These problems derive from the fact that the provider has access to the systems and data of many clients. On some occasions, those clients can even be direct competitors, which is why the confidentiality of the information referring to them must be ensured (Grover and Teng, 1993; Grover, Cheon and Teng, 1994; Alner, 2001).

h) Unclear Cost/Benefit Relationship. Taking into account all the factors which are relevant to outsourcing and trying to translate them into monetary terms is no easy task. The difficulty to assess the provider's contribution may generate disagreements in the quality/price ratio of the services acquired (Bahli and Rivard, 2002, 2005).

i) Irreversibility of the Decision. It is hard to revert the process after certain IS functions have been outsourced; and much more so if the client has opted for total outsourcing (Earl, 1996; Harland, Knight, Lamming and Walker, 2005).

j) Possible Staff Opposition. The fact that the client company's staff may see outsourcing as a threat to their jobs is at the root of this possible opposition (Grover, Cheon and Teng, 1994; Brooks, 2006).

k) Staff Problems. The situation of uncertainty generated by IS outsourcing is likely to result in problems such as low productivity, loss of motivation, low morale, anxiety, insecurity, etc. among the client company's IS department staff (Grover and Teng, 1993; Walden and Hoffman, 2007).

After proposing our set of reasons and risks, it is now time to assess them with a field study.

\section{METHODOLOGY}


The directory Las 5.000 Mayores Empresas [The largest 5,000 companies] of the magazine Actualidad Económica [Economic Current News] was used to determine the study population, collating it with Duns and Bradstreet's database 50.000 Principales empresas Españolas [The main 50,000 Spanish companies]. A total of 45 companies were discarded among the 5,000 companies with the highest turnover from the first database because their address and telephone number coincided with those of other firms, which suggested that they were subsidiaries of the former. The remaining 4,955 companies received a questionnaire in two formats, first electronic and then in paper.

A total of 7 questions -out of the 28 questions included in this survey questionnaire- have been used in the present paper, which forms part of a broader research on different aspects of IS outsourcing. The questionnaire stems from two previous ones prepared by the same authors which -the same as this one- are based on a review of the literature about IS Outsourcing. Table 3 shows the measures about the main two variables examined in the study.

\section{INSERT TABLE 3}

The survey addressee was the IS manager of the selected companies. Also IS executives answered the questionnaire in other studies about IS outsourcing -for instance, the one carried out by Shi (2010). The information obtained was subsequently elaborated upon using the SPSS statistical software.

Table 4 lists the study technical specifications. Since part of the present study is focused on analyzing the evolution in time of our interviewees' answers through the three surveys performed by the same authors, Table 4 offers the information corresponding to the most recent interview as well as that referring to the two preceding ones. A total of 398 valid responses were obtained in the last survey between October 2012 and February 2013, 
which means that the survey results collect the answers from $8 \%$ of the population examined.

INSERT TABLE 4

The profile of companies which answered this third survey is representative of the overall population (measured by sales) and the activity sector.

\section{RESULTS AND DISCUSSION}

\subsection{General characteristics of companies and their IS departments}

Table 5 shows the general features of the interviewed firms and their departments. They are not the focus of this study but help us to determine if the reasons and risks linked to outsourcing are perceived differently by firms depending of these characteristics.

\section{INSERT TABLE 5}

\subsection{IS Outsourcing Reasons}

The reasons why -according to interviewees- companies decide to outsource their IS activities are listed in order, from more to less important, in Table 6. It can be observed that the most important ones are: Being Able to Focus on Strategic Issues; Increasing IS Department Flexibility; and Improving Quality in the services that the IS delivers to the company. At the other end, the least important reason is: Joining the Fashion -that is, outsourcing because other companies do so.

\section{INSERT TABLE 6}

Special attention should be paid to analyzing the means, as well as the medians and modes, of the items referring to outsourcing reasons -all of them above 4 on a 1-to-7 Likert scale. It is worthy of mention that, save for Joining the Fashion, all the other reasons are considered important or very important for outsourcing. 
A Principal Components Factor Analysis was subsequently carried out with the items corresponding to Outsourcing Reasons. The objective sought with this analysis was to be able to reduce the initial information offered by the original variables to a smaller set of factors, thus detecting the underlying factors or constructs in the information provided by the original items. It can be checked that carrying out the factor analysis is pertinent because the correlation determinant matrix is close to zero, the Kaiser-Meyer-Olkin is situated between 0 and 1 -above $0.5-$ and Bartlett's test of Sphericity is significant (Bartlett, 1950) ${ }^{1}$.

The Principle Components Factor Analysis reveals 3 Eigenvalues above 1, which suggests the advisability of extracting three factors that explain $60 \%$ of the information supplied by the original variables (a satisfactory ratio, being above 50\%). A Varimax rotation was carried out so that factors could be better interpreted, and Table 7 allows us to show the resulting factors as well as the original items which play the most important role in their formation.

\section{INSERT TABLE 7}

- The first factor can be called Strategic Reasons, as it comprises the items related to the possibility for the Company to Focus on strategic issues thanks to Outsourcing, to Increasing IS Department Flexibility, to Improving Service Quality, and to Getting Rid of the most monotonous IS tasks.

- The second Factor is given the name of Technological Reasons, since it comprises Facilitating Access to Technology, Reducing the Risk of Technological Obsolescence, Having Alternatives to the Internal IS and -with lesser weight- Joining the Fashion.

\begin{tabular}{|l|r|}
\hline Correlation Matrix Determinant & 0.081 \\
Kaiser-Meyer-Olkin Index & 0.757 \\
Bartlett's Test of Sphericity & 922.440 \\
Significance & 0.000 \\
\hline
\end{tabular}


- As for the third Factor, it corresponds to Economic Reasons because it includes the possibility that outsourcing offers to Reduce Costs, both technology-related and staffrelated ones.

The percentage of contribution made by each factor to variance allows us to see that the first factor is the most important one (it explains $33 \%$ of the total variance), followed by the second one (which accounts for 16\%) and the third (explaining only 10\%). This can help us interpret that, according to interviewees, strategic reasons are now more relevant than technological reasons -and even more than economic ones- when it comes to outsourcing, something that reinforces the conclusions drawn from unidimensional analysis (Table 6).

After obtaining these three factors, the next step is to analyze the extent to which those factors are more or less important in the different types of companies -an aspect that will be studied with a mean equality test in Table 8 .

\section{INSERT TABLE 8}

Table 8 describes us that the largest companies (with more workers and more income) resort to outsourcing above all for strategic reasons. Lower-income companies also decide to outsource but more often than not due to economic reasons. The companies which outsource the most (above the average) seek outsourcing for strategic reasons -but also for economic ones. Companies with a lower staff in their IS departments especially value economic reasons when it comes to outsourcing.

\subsection{IS Outsourcing Risks}

\section{INSERT TABLE 9}

IS Outsourcing Risks will be analyzed next by means of Table 9. The first striking aspect is the importance assigned to nearly all these risks. Except for the last two, they all have their median and mode above 4 -the means of all but the last four additionally exceeding 4 
(which is the average on the 1-to-7 Likert scale). This leads us to recommend the list of risks proposed; on the whole, every one of these risks should be taken into account when it comes to IS outsourcing. Nevertheless, it is worth highlighting that issues associated with staff -such as their possible opposition- are the least problematic for outsourcing according to interviewees.

It can additionally be seen that the most important risks include: the provider's staff not being suitably qualified; the client having an excessive dependence on the provider; the provider failing to comply with the contract established; and the loss of knowledge by the client after outsourcing.

A Principal Components Factor Analysis is carried out once again -this time with the items linked to outsourcing risks. For that purpose, the first step consisted in checking that the analysis was statistically pertinent, ${ }^{2}$ after which two factors were extracted following Kaiser's criterion -according to which it is pertinent to extract as many factors as eigenvalues above one exist. An additional factor matrix rotation using the Varimax method helped us interpret them (Table 10)

\section{INSERT TABLE 10}

Table 10 shows us that it is possible to explain $49.895 \%$ of the information supplied by the original variables with two extracted factors. This is a low percentage -below 50\%, which is the value recommended as the minimum, though very close to it. ${ }^{3}$

The two extracted factors have been called Client's Risks and Provider's Risks. It can be clearly seen that Factor 1 accumulates all the risks more directly associated with the actual

\begin{tabular}{|l|r|}
\hline Correlation Matrix Determinant & 0.031 \\
Kaiser-Meyer-Olkin Index & 0.815 \\
Bartlett's Test of Sphericity & $1,281.439$ \\
Significance & 0.000 \\
\hline
\end{tabular}

\footnotetext{
${ }^{3}$ Furthermore, performing this same analysis with three factors did not allow us to comply with Kaiser's criterion, and the cumulative explained variance did not increase to a large extent (only up to 58.556\%); hence our decision to extract two factors.
} 
client, such as: Staff-related Problems; the Client's possible Loss of Knowledge; the Irreversibility of the Decision made; or not having a very clear idea of the relationship between outsourcing Costs and Benefits. Instead, the second risk includes those risks

which can more easily be attributed to the provider, among them: Lack of Qualification of its Staff; Lack of Compliance with the Contract; or the Provider's Inability to Adapt to Technology.

It is worth noting that, unlike what happened in the previous factor analysis, there is no great difference between the variance percentage explained by the first factor and that accounted for by the second one. This suggests that the first factor is not significantly more important than the second; both have almost the same statistical weight.

The observation of the mean difference between the factors corresponding to outsourcing risks and different company characteristics did not reveal any significant contrast. Therefore, it cannot be said that different types of risks are more typical in one type of company or another.

\subsection{Outsourcing Reasons and Risk: 2013-2006-2001 Study}

Table 11 allows us to see the evolution in the ranking of outsourcing reasons and risks through the three surveys carried out with companies of a similar profile at different moments in time.

The first remarkable finding is the high stability in the ranking of most important reasons to outsource. At three different moments in time, the first 4 reasons remain the same - and in the same order as well. Furthermore, the 2006 and 2013 surveys show a practically identical reasons ranking, which reinforces that stability. It clearly follows from this ranking, at least in our interviewees' words, that companies seek outsourcing for strategic reasons, to increase IS department flexibility and, in short, to offer higher quality getting 
rid of the most monotonous tasks. Technology-based reasons are important but not so much and, finally, cost savings should be considered -though not as the most essential reason.

With regard to risks, their assessment has moved a little more in the ranking. Focusing on the four most important risks, it is true that they have remained the same in the three surveys carried out (which cover a 12-year period) but the order has changed. Also the least important risks are the same in the last two surveys.

INSERT TABLE 11

\section{CONCLUSIONS}

Major Spanish companies follow the trend to outsource their IS services, thus joining the current of evolution suggested by analysts and academics (ZDNet, 2007; Cox, Roberts and Walton, 2011). The first contribution made by our paper lies in the fact that it contrasts the validity of the outsourcing reasons suggested in previous works (Gonzalez, Gasco and Llopis 2005a, 2010). Interviewees gave an assessment above the average to all the reasons to outsource that were presented to them, except for Joining the Fashion, to which must be added that, although they could do so, they did not suggest any additional reasons for IS outsourcing.

The outsourcing reasons proposed in our survey can be summarized into strategic, technological and economic ones, following the already classical taxonomy developed by Cheon, Grover and Teng $(1994,1996)$. It was verified that reasons of a strategic nature are the most relevant ones when it comes to outsourcing, followed by technological reasons and, finally by those related to economic aspects. A confirmation has also been obtained that outsourcing, which was originally focused on the cost savings that it could mean for the company, is now justified by a wide variety of reasons which have to do with the 
improvement of IS services, with the flexibility that it gives to the computer department, and with the chance for the firm to pay the most attention to strategic issues (Willcocks, Feeny and Olson, 2006). It additionally deserves to be mentioned that strategic reasons have been confirmed as the most important ones for larger-sized companies, and also for those which outsource to a greater extent. Therefore, it is checked that companies are not outsourcing due to a lack of resources; instead, outsourcing is being adopted as an improvement strategy. Only firms with smaller staff numbers in their IS department -and consequently with fewer resources- resort to outsourcing for essentially economic reasons. It is worth highlighting the great stability in the ranking of reasons adduced by interviewees over time -as proved by our three surveys. Both in the 2001 survey and in those carried out in 2006 and 2013, strategic reasons are confirmed as the most important, followed by technological ones and, finally, by those related to economic aspects $-\mathrm{a}$ trend that has continued in recent years.

In relation to risks, the strong endorsement given by interviewees to the list proposed is equally outstanding -which means that all the risks mentioned should be taken into account when it comes to outsourcing. Even though a factor analysis leads us to summarize these risks into those which can be attributed to the provider and those stemming from the client, it is difficult for us to determine which ones are more important. While the survey carried out in 2001 mostly gave higher assessments to risks associated with the client, provider-related risks occupied a prominent position in the 2006 survey; and the most recent study shows a mixture of risks attributed to both parties. This may be due to the fact that the greater maturity achieved by many outsourcing contracts and relationships, where a much closer connection exists with providers (Gonzalez, Gasco and Llopis, 2014), can make clients become more aware of the risks involved in outsourcing -as a result of which those risks are no longer seen as deriving only from the provider. 
In addition to the set of outsourcing reasons and risks proposed and contrasted in the present paper, the use of a longitudinal analysis deserves to be highlighted as an important contribution too, insofar as most research studies are like a snapshot taken at a particular point in time, and the longitudinal vision can provide a fresher approach (Dibbern, Goles, Hirschheim and Jayatilaka, 2004).

This study continues to adopt a perspective focused on the opinions of outsourcing clients, a limitation which should be overcome with more studies about IS outsourcing from the provider's point of view. Likewise, our analysis starts from the reality of the largest Spanish companies, which is why extrapolating these results to other countries and to different types of firms may prove risky.

\section{BIBLIOGRAPHIC REFERENCES}

Abdullah, L.M. and Verner, J.M. (2012). "Analysis and application of an outsourcing risk framework." The Journal of Systems and Software. 85(8), pp. 1930-1952.

Al-Gharbi, K.; Al-Kindi, A. and Al-Salti, Z. (2009). "IT/IS Outsourcing from Omani Organizations' Perspective: Motivations and Reservations". International Journal of Management Innovations Systems. 1(1), pp. 1-10.

Alner, M. (2001). "The effects of Outsourcing in Information Security". Information Systems Security. 10(2), pp. 35-43.

Ang, S. and Cummings, L.L. (1997). "Strategic Response to Institutional Influences on Information Systems Outsourcing”. Organization Science. 8(3), pp. 235-256.

Ang, S. and Straub, D. (1998). "Production and Transaction Economies and IS Outsourcing: A Study of the U.S. Bank Industry." MIS Quarterly. 22(4), pp. 535-552.

Bahli, B. and Rivard, S. (2002). A Validation of Measures Associated with the risk Factors in Information Technology Outsourcing. Proceedings of the 36th Hawaii International Conference on Systems Sciences (HICSS'03).

Bahli, B. and Rivard, S. (2005). "Validating Measures of Information Technology Outsourcing Risks Factors." Omega. 33(2), pp.175-187.

Baldwing, LP; Irani, Z. and Love, P. (2001). "Outsourcing Information Systems: Drawing Lessons from a Banking Case Study.” European Journal of Information Systems. 10(1), pp. 15-24.

Barthélemy, J. (2001). “The Hidden Cost of IT Outsourcing.” MIT Sloan Management Review. 42(3), pp. 6069.

Bartlett, M. S. (1950). "Tests of significance in factor analysis.” British Journal of Statistical Psychology. 3(2), pp. 77-85.

Brooks, N. (2006). "Understanding IT Outsourcing and its Potential Effects on IT Workers and Their Environment." The Journal of Computer Information Systems. 46(4), pp. 46-53.

Clark, T.D.; Zmud, R.W. and McCray, G.E. (1995). "The Outsourcing of Information Services: Transforming the Nature of Business in the Information Industry." Journal of Information Technology. 10, pp. 221-237.

Cox, M.; Roberts, M. and Walton, J. (2011). "Motivations for IT Outsourcing in Public Sector Local Government." Proceedings of the 2nd International Conference on Information Management and Evaluation. Toronto. Canada, pp. 141-149.

Dibbern, J.; Goles, T.; Hirschheim, R. and Jayatilaka, B. (2004). "Information Systems Outsourcing: a survey and analysis of the literature." Database for Advances in Information Systems. 35(4), pp. 6-102. 
Earl, M.J. (1996). “The Risk of Outsourcing IT.” Sloan Management Review. 37(3), pp. 26-32.

Fan, Z-P.; Suo, W-L. and Feng, B. (2012). "Identifying risks factors of IT outsourcing using interdependent information: An extended DEMATEL method." Expert Systems with Applications. 39 (3), pp. 38323840.

Gandhi, S. J.; Gorod, A. and Sauser, B. (2012). "Prioritization of outsourcing risks from a systemic perspective." Strategic Outsourcing: An International Journal. 5(1), pp. 39-71.

Gonzalez, R.; Gasco, J. and Llopis, J. (2005a). "Information Systems Outsourcing reasons in the largest Spanish firms." International Journal of Information Management. 25(2), pp. 117-136.

Gonzalez, R.; Gasco, J. and Llopis, J. (2005b). "Information systems outsourcing risks: a study of large firms." Industrial Management \& Data Systems. 105 (1), pp. 45-62.

Gonzalez, R.; Gasco, J. and Llopis, J. (2010). "Information Systems Outsourcing Reasons and Risks: A New Assessment." Industrial Management \& Data Systems. 110(2), pp. 284-303.

Gonzalez, R, Gasco, J. and Llopis, J. (2014). "Contratos y relaciones de outsourcing de sistemas de información: un estudio en grandes empresas españolas." XXIV Congreso Nacional de ACEDE. Castellón.

Grover, V.; Cheon, M.J. and Teng, T.C. (1994). "A Descriptive Study on the Outsourcing of Information Systems Functions.” Information \& Management. 27(1), pp. 33-44.

Grover, V.; Cheon, M.J. and Teng, T.C. (1996). "The Effect of Service Quality and Partnership on the Outsourcing of Information Systems Functions." Journal of Management Information Systems. 12(4), pp. 89-116.

Grover, V. and Teng, J.T.C. (1993). "The Decision to Outsource Information Systems Functions.” Journal of Systems Management. November, pp. 34-38.

Gupta, G. and Gupta, H. (1992). "Outsourcing the IS function. Is it necessary for your organization?" Information Systems Management. 9(3), pp. 44-50.

Harland, Ch.; Knight, L.; Lamming, R. and Walker, H. (2005). "Outsourcing: assessing the risks and benefits for organisations, sectors and nations." International Journal of Operations \& Production Management. 25(9), pp. 831-850.

Hayes, D.C.; Hunton, J.E. and Reck, J.J. (2000). "Information Systems Outsourcing Announcements: Investigating the Impact on the Market Value of Contract-Granting Firms." Journal of Information Systems. 14(2), pp. 109-125.

Hurst, I. and Hanessian, B.G. (1995). "Navigating IT Channels: Integrate or Outsource?" The McKinseyQuarterly. (3), pp. 103-110.

Jain, R.K. and Natarajan, R. (2011). "Factors Influencing Outsourcing Decisions: a Study of the Banking Sector in India." Strategic Outsourcing: An International Journal. 4(3), pp. 294-322.

Jurison, J. (1995). "The Role of Risk and Return in Information Technology Outsourcing Decisions." Journal of Information Technology. 10(4), pp. 239-247.

Kotlarsky, J. and Willcocks, L. (2012). "Special Issue on Global Sourcing of Business and IT Services." Journal of Information Technology Teaching Cases. 2, pp. 57-60.

KPMG (2013): State of the outsourcing Industry 2013. Executive Findings. Internet document. Retrieved 12/12/2013. http://www.kpmginstitutes.com/shared-services-outsourcinginstitute/insights/2013/pdf/state-of-outsourcing-2013-exec-findings-hfs.pdf

Lacity, M. and Hirschheim, R. (1993a). "Implementing Information Systems Outsourcing: Key Issues and Experiences of an Early Adopter.” Journal of General Management. 19(1), pp. 17-31.

Lacity, M. and Hirschheim, R. (1993b). "The information systems outsourcing Bandwagon." Sloan Management Review. 35(1), 73-86.

Lacity, M.; Hirschheim, R. and Willcocks, L. (1994). "Realizing Outsourcing Expectations. Incredible Expectations, Credible Outcomes.” Information Systems Management. 11(4), pp. 7-18.

Nakatsu, R.T. and Iacovou, Ch.L. (2009). "A comparative study of important risks factors involved in offshore and domestic outsourcing of software development projects: A two-panel Delphi study." Information and Management. 46(1), pp. 57-68.

Ngwenyama, O.K. and Sullivan, W.E. (2007). "Outsourcing Contracts as Instruments of Risks Management. Insights from two Successful Public Contracts." Journal of Enterprise Information Management. 20(6), pp. 615-640.

McFarlan, F.W. and Nolan, R.L. (1995). "How to Manage an IT Outsourcing Alliance". Sloan Management Review. 36(2), pp. 8-23.

McLellan, K.; Marcolin, B. and Beamish, P. (1995). "Financial and Strategic Motivations behind IS Outsourcing." Journal of Information Technology. 10(4), pp. 299-321.

Palvia, P.C. (1995). "A Dialectic View of Information Systems Outsourcing: Pros and Cons." Information \& Management. 29(5), pp. 265-275. 
Shi, Z. (2010). "The role of IS architecture planning in Enhancing IS Outsourcing's Impact on IS Performance: Its antecedents and an empirical test." Journal of Enterprise Information Management. 23(4), pp. 439-465.

Slaughter, S. and Ang, S. (1996). "Employment Outsourcing in Information Systems." Communications of the ACM. 39(7), pp. 47-54.

Smith, M.A.; Mitra, S. and Narasimhan, S. (1998). "Information Systems Outsourcing: A Study of Pre-Event Firm Characteristics." Journal of Management Information Systems. 15(2), pp. 61-93.

Sullivan, W. and Ngwenyama, O.K. (2005). "How are public sector organizations managing IS outsourcing risks? An Analysis of Outsourcing Guidelines from three Jurisdictions." The Journal of Computer Information Systems. 45(3), pp. 73-87.

Verwaal, E.; Verdu, A.J. and Recter, A. (2008). "Transaction Cost and organizational learning in strategic outsourcing relationships". International Journal of Technology Management. 41(1-2), pp. 38-54.

Walden, E.A. and Hoffman, J.J. (2007). "Organizational form, incentives and the management of Information Technology. Opening the black box of Outsourcing." Computers \& Operations Research. 34(12), 3575-3591.

Willcocks, L.P.; Lacity, M.C. and Kern, T. (1999). "Risk Mitigation in IT Outsourcing strategy revisited: Longitudinal case research at LISA." Journal of Strategic Information Systems. 8(3), pp. 285-314.

Willcocks, L.P.; Feeny, D. and Olson, N. (2006). "Implementing core IS capabilities: Feeny-Willcocks IT governance and management framework revisited." European Management Journal. 24(1), 28-37.

Yang, D-H.; Kim, S.; Nam, Ch. and Min, J-W. (2007). "Developing a decision model for business process outsourcing." Computers and Operations Research. 34(2), 3769-3778.

ZDNet (2007): "87\% of Outsourcing Buyers to Continue Outsourcing," Internet Document. http://blogs.zdnet.com/ITFacts/index.php?cat=29. 
Table 1: Review of the Literature about IS Outsourcing Reasons

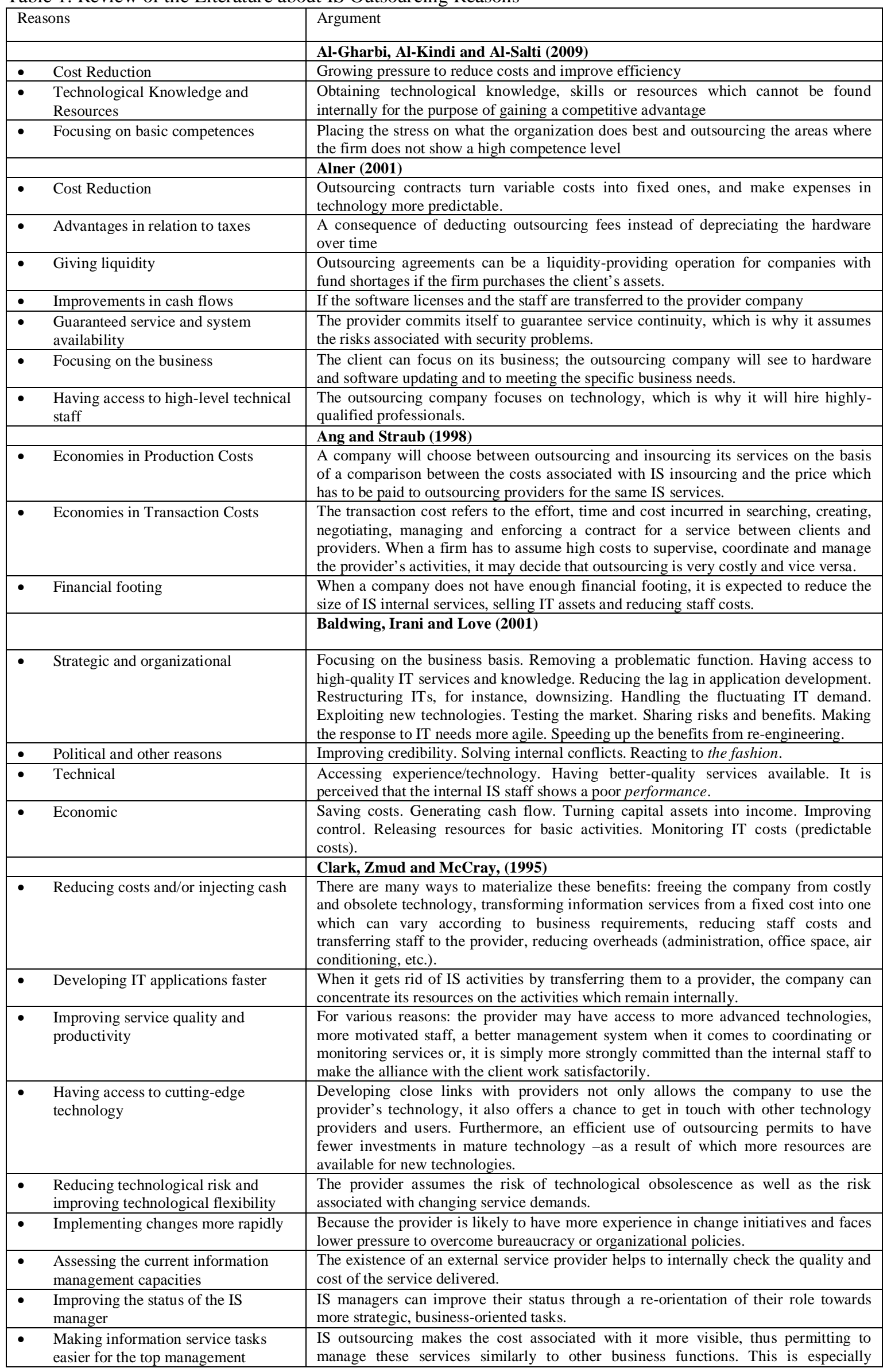




\begin{tabular}{|c|c|}
\hline & $\begin{array}{l}\text { attractive to the top management, when the CIO is unable to show the benefits } \\
\text { obtained from the investment in IT. }\end{array}$ \\
\hline & Cox, Roberts and Walton ( 2011) \\
\hline Improving quality & Improving IS quality \\
\hline - $\quad$ Cost savings & Cutting costs in staff and/or technology \\
\hline Access to experts & The provider's staff has experience that can prove useful to the client \\
\hline - $\quad$ Recruitment problems & The client avoids the problem of hiring well-trained and skilled staff \\
\hline - $\quad$ Focusing on basic competences & $\begin{array}{l}\text { Outsourcing the most superfluous aspects can help the company focus on its basic } \\
\text { competences. }\end{array}$ \\
\hline - $\quad$ Flexibility & $\begin{array}{l}\text { Acquiring flexibility in IS management through a partnership agreement with the } \\
\text { provider }\end{array}$ \\
\hline \multirow[t]{2}{*}{ - $\quad$ Cost restructuring } & $\begin{array}{l}\text { Turning the fixed costs associated with the firm's own IS into variable ones linked to } \\
\text { the monthly payment of the outsourcing contract fees. }\end{array}$ \\
\hline & Grover, Cheon and Teng $(1994 ; 1996)$ \\
\hline - $\quad$ Strategic Factors & $\begin{array}{l}\text { Companies can focus on basic business competences. It also allows the IS staff to } \\
\text { concentrate on the strategic use of ITs, outsourcing the most monotonous, routine } \\
\text { tasks. Access to IS-specialist staff. }\end{array}$ \\
\hline - $\quad$ Economic Factors & $\begin{array}{l}\text { The outsourcing provider obtains economies of scale in hardware, software and staff } \\
\text { areas, since it attends to projects with various clients. The provider also obtains } \\
\text { economies of scope because a variety of IT tasks are performed. These economies are } \\
\text { partly taken advantage of by the client. Furthermore, outsourcing permits to control } \\
\text { IT-related costs and also to make those costs predictable. }\end{array}$ \\
\hline \multirow[t]{2}{*}{ - Technological Factors } & $\begin{array}{l}\text { Access to cutting-edge IT, which is the one available to the service provider. Avoiding } \\
\text { the risk of technological obsolescence which results from dynamic changes in IT. }\end{array}$ \\
\hline & Grover and Teng (1993) \\
\hline $\begin{array}{l}\text { - } \quad \text { Focusing on Basic Business } \\
\text { Competences }\end{array}$ & Companies can concentrate once again on what constitutes their own business. \\
\hline $\begin{array}{ll} & \text { Re-orienting themselves towards } \\
\text { strategic IT activities }\end{array}$ & $\begin{array}{l}\text { Focusing on activities which promote competitiveness instead of the most } \\
\text { monotonous, routine tasks }\end{array}$ \\
\hline $\begin{array}{l}\text { Benefiting from providers' } \\
\text { competence }\end{array}$ & $\begin{array}{l}\text { It is possible to enjoy the competences owned by the provider without the need to } \\
\text { adopt them internally. }\end{array}$ \\
\hline $\begin{array}{l}\text { - Transferring the problem of } \\
\text { managing and training IT staff }\end{array}$ & $\begin{array}{l}\text { Training internal IT staff and keeping them up-to-date poses a huge challenge during } \\
\text { periods of great technological changes. }\end{array}$ \\
\hline $\begin{array}{l}\text { - Benefiting from the provider's } \\
\text { economies of scale and scope }\end{array}$ & $\begin{array}{l}\text { The provider obtains economies of scale and scope for delivering identical or similar } \\
\text { services to different clients; the client can benefit from obtaining these services at a } \\
\text { lower cost. }\end{array}$ \\
\hline - $\quad$ Monitoring costs without ambiguity & The client can plan the costs derived from the IT services delivered. \\
\hline \multirow[t]{2}{*}{$\begin{array}{l}\text { Facilitating access to some } \\
\text { technologies }\end{array}$} & $\begin{array}{l}\text { Some technologies which the client finds very expensive or hard to manage can be } \\
\text { enjoyed thanks to outsourcing. }\end{array}$ \\
\hline & Gupta and Gupta (1992) \\
\hline - $\quad$ Focus on strategy & $\begin{array}{l}\text { Dynamic organizations analyze what they do best and how they can do it better. These } \\
\text { organizations do not see outsourcing as an individual decision which affects a single } \\
\text { IT project or aspect; instead, they regard outsourcing as a strategic decision which can } \\
\text { have long-term effects on the whole organization. }\end{array}$ \\
\hline - Economic considerations & $\begin{array}{l}\text { Many outsourcing contracts have a fixed price, which eliminates the problem of the } \\
\text { uncertain costs associated with ITs. The costs of IS operations decreases by the } \\
\text { provider's economies of scale. Of course, IS staff can be reduced -thus implying cost } \\
\text { savings. }\end{array}$ \\
\hline - $\quad$ Market forces & $\begin{array}{l}\text { Mergers, acquisitions and the re-sizing of a company are the market forces which push } \\
\text { towards IS outsourcing, since the outsourcing of operations which are not considered } \\
\text { essential for the organization reduces bureaucracy and improves the ability to respond } \\
\text { to market forces. }\end{array}$ \\
\hline \multirow[t]{2}{*}{ - $\quad$ Technical considerations } & $\begin{array}{l}\text { The company may lack the technical experience required to develop or introduce new } \\
\text { technology. }\end{array}$ \\
\hline & Harland, Knight, Lamming and Walker (2005) \\
\hline - $\quad$ Focusing on what is basic & The company must concentrate on its competitive advantages. \\
\hline Reducing costs & Short-term benefits are achieved. \\
\hline - $\quad$ Improving flexibility & When the company does not own so many own resources \\
\hline $\begin{array}{l}\text { - Enhancing the ability to respond to } \\
\text { changes }\end{array}$ & The client can change the service demanded as its needs change. \\
\hline $\begin{array}{l}\text { - Benefits through economies of scale } \\
\text { and scope }\end{array}$ & Clients can enjoy better prices thanks to the provider's economies of scale and scope. \\
\hline $\begin{array}{l}\text { - Ability to access the best knowledge } \\
\text { and capabilities }\end{array}$ & The provider's staff's knowledge and skills \\
\hline $\begin{array}{ll}\text { - } & \text { Freeing itself from culture-related } \\
\text { restrictions and internal attitudes }\end{array}$ & Outsourcing is very often accompanied by a re-engineering of internal processes. \\
\hline \multirow[t]{2}{*}{ - $\quad$ Access to new, creative ideas } & Transfer of Know-How from providers to clients \\
\hline & Hayes, Hunton and Reck (2000) \\
\hline
\end{tabular}




\begin{tabular}{|c|c|}
\hline - $\quad$ Economies of scale and scope & $\begin{array}{l}\text { IT providers are always exposed to a wider variety of problems and experiences } \\
\text { related to IS; that is why they can obtain higher economies of scale and scope. }\end{array}$ \\
\hline - Importance of basic competences & $\begin{array}{l}\text { The outsourcing of non-basic functions permits to transfer resources to other functions } \\
\text { which are really basic. }\end{array}$ \\
\hline - $\quad$ Flexibility & $\begin{array}{l}\text { Companies can increase their flexibility by continuously redesigning contracts in order } \\
\text { to cover their information needs. }\end{array}$ \\
\hline \multirow[t]{2}{*}{ - $\quad$ Cost reduction } & $\begin{array}{l}\text { This reduction is based on the economies of scale and scope obtained by the provider } \\
\text { which are partly transferred to the client. }\end{array}$ \\
\hline & Jurison (1995) \\
\hline $\begin{array}{l}\text { - Cost savings through economies of } \\
\text { scale }\end{array}$ & $\begin{array}{l}\text { The provider can often obtain economies of scale which may not be achieved } \\
\text { internally -this can impact to some extent on the client's savings. }\end{array}$ \\
\hline - $\quad$ Liquidity-providing operation & $\begin{array}{l}\text { It happens with the transfer of assets (for example, hardware) from the client to the } \\
\text { provider. }\end{array}$ \\
\hline - A faster development of applications & Providers are experts in development and that is why they can do it faster. \\
\hline - It improves quality and service & The provider can offer an improved service and quality in IS functions. \\
\hline - $\quad$ Access to IT experts & Some companies may find it difficult or expensive to hire new staff. \\
\hline - $\quad$ Access to new technologies & Those which the provider is going to supply \\
\hline $\begin{array}{l}\text { - } \quad \text { Flexibility when managing IT } \\
\text { resources }\end{array}$ & $\begin{array}{l}\text { Dealing more easily with the growing volatility in business levels and letting the } \\
\text { provider assume the fluctuations in IT workloads. }\end{array}$ \\
\hline \multirow[t]{2}{*}{ - Removing a problematic function } & That function will be managed by the provider. \\
\hline & Lacity and Hirschheim (1993a) \\
\hline - $\quad$ Cash injection & Companies may need a cash injection, and outsourcing is a way to achieve it. \\
\hline $\begin{array}{l}\text { - } \begin{array}{l}\text { Perception that the IS is not } \\
\text { efficient/effective }\end{array}\end{array}$ & $\begin{array}{l}\text { If the IS has problems such as lack of standards, lack of control, staff-related trouble, } \\
\text { etc. it is perceived that, being a professional, the provider will manage the IS function } \\
\text { more effectively. }\end{array}$ \\
\hline $\begin{array}{l}\text { - Perception that the IS is not } \\
\text { technically competent }\end{array}$ & $\begin{array}{l}\text { The provider can more easily adapt to changes in technologies, both in hardware and } \\
\text { in software. }\end{array}$ \\
\hline \multirow[t]{2}{*}{ - $\quad$ Focusing on more strategic problems } & $\begin{array}{l}\text { If non-strategic functions are outsourced, the company can concentrate on the most } \\
\text { strategic problems. }\end{array}$ \\
\hline & Lacity, Hirschheim and Willcocks (1994) \\
\hline - $\quad$ Financial Factors & $\begin{array}{l}\text { Reducing costs, above all through the economies of scale obtained by the provider } \\
\text { when delivering these services. Improving cost control, since providers implement } \\
\text { controls that link use directly to cost. Restructuring IT budgets, making them more } \\
\text { flexible. }\end{array}$ \\
\hline - $\quad$ Business Factors & $\begin{array}{l}\text { Returning to basic competences, outsourcing those IS functions which are not } \\
\text { strategic. Facilitating merger and acquisition processes because outsourcing provides a } \\
\text { solution to technical incompatibilities; absorbing the excess of IT assets, or the } \\
\text { additional IS employees who result from this processes. Providing IT to newly-created } \\
\text { companies, because outsourcing is seen as a faster and less expensive way to deliver } \\
\text { IT services when the new firms cannot afford the capital investment required to set up } \\
\text { an internal IS department. }\end{array}$ \\
\hline - $\quad$ Technical Factors & $\begin{array}{l}\text { Access to technical knowledge, since many companies find it difficult to hire and } \\
\text { retain staff with the knowledge required. Gaining access to new technologies thanks to } \\
\text { the availability of products from the provider's large Research and Development } \\
\text { departments. }\end{array}$ \\
\hline \multirow[t]{2}{*}{ - $\quad$ Political Factors } & $\begin{array}{l}\text { Checking the IS department's efficiency, because an evaluation of the provider's } \\
\text { offers can prove that the internal IT department actually offered IS services at a } \\
\text { cheaper price. Justifying new resources, as equipment or staff enlargements, when it is } \\
\text { checked that outsourcing would not reduce the cost of obtaining additional IT } \\
\text { resources. Copying the success of other companies which have already outsourced. } \\
\text { Eliminating a problematic function, because they can very often become a 'headache' } \\
\text { for the top management. Breaking the 'glass ceiling,' since IS managers rarely reach } \\
\text { the highest steps of management; their professional ceiling is defined, and subjecting } \\
\text { their function to an outsourcing assessment allows them to demonstrate that they are } \\
\text { not technocrats but businessmen who are willing to outsource in the company's } \\
\text { interests. }\end{array}$ \\
\hline & McFarlan and Nolan (1995) \\
\hline
\end{tabular}




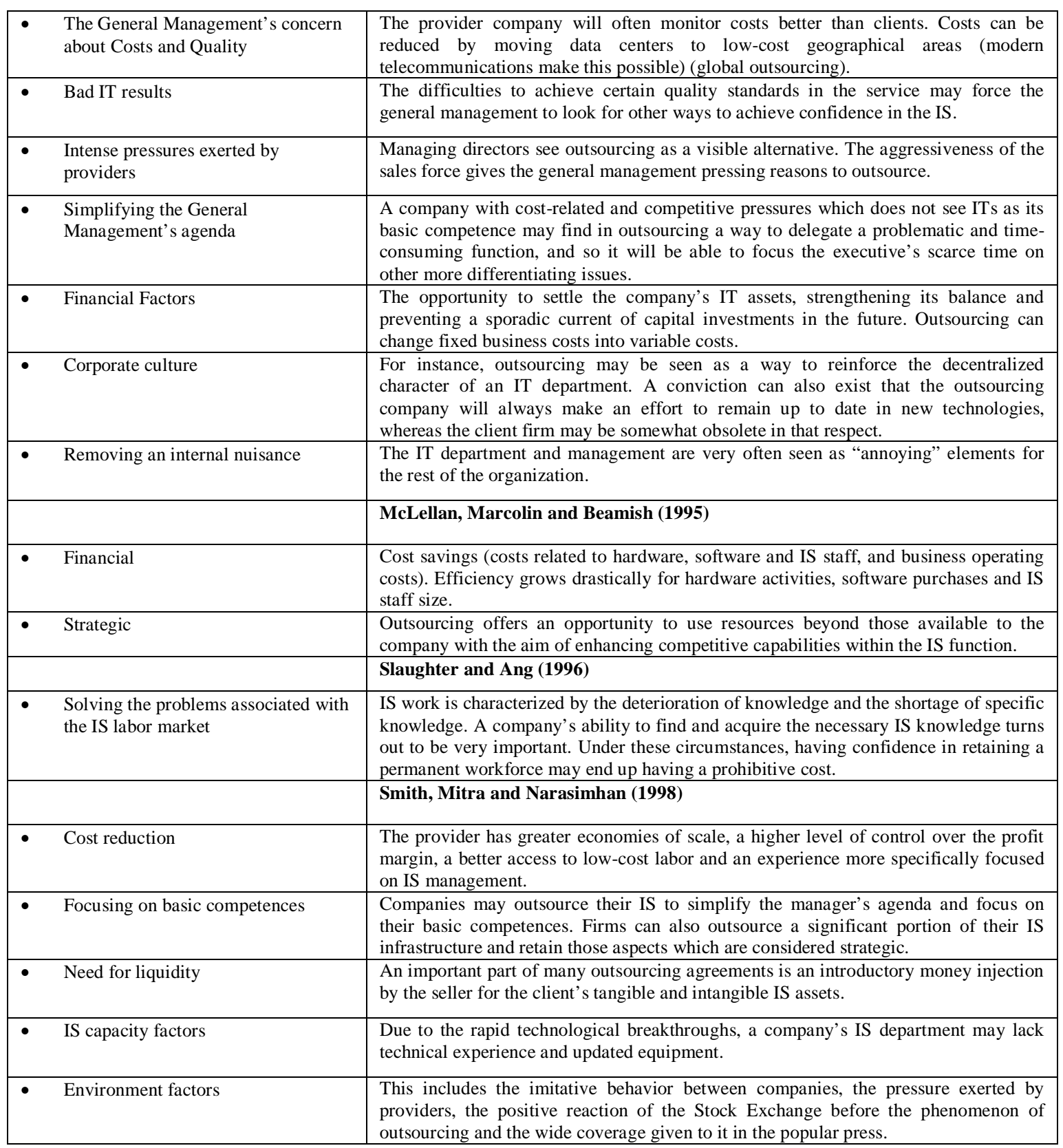


Table 2: Review of the Literature on IS Outsourcing Risks

\begin{tabular}{|c|c|}
\hline Risk & Argument \\
\hline & Abdullah and Verner (2012) \\
\hline - $\quad$ Organizational environment & $\begin{array}{l}\text { Change in the management, corporate policy with negative effects, a corporate culture which } \\
\text { does not give support, different geographical locations, Lack of support from the top } \\
\text { management, Organizational Restructuring, a deficient cultural fit between client and seller, } \\
\text { etc. }\end{array}$ \\
\hline - $\quad$ Team & $\begin{array}{l}\text { Lack of client cooperation, lack of client confidence, communication problems, conflicts } \\
\text { between client and seller, divergent work styles, lack of experience in outsourcing or } \\
\text { contract management, loss of key employees, negative attitudes, etc. }\end{array}$ \\
\hline User & Conflict between users, lack of participation by the latter, unreal expectations, etc. \\
\hline - $\quad$ Complexity & $\begin{array}{l}\text { High technical complexity level, high complexity in tasks, many sellers, use of new } \\
\text { technology, utilization of technology which has not been used in previous projects, etc. }\end{array}$ \\
\hline - $\quad$ Contract & $\begin{array}{l}\text { Failure to specify the appropriate measures, lack of flexibility, penalties for non-compliance } \\
\text { are not specified in the contract, etc. }\end{array}$ \\
\hline Financial & Exchange rate fluctuation, hidden costs, insufficient financing, etc. \\
\hline - $\quad$ Legal & $\begin{array}{l}\text { Inadequate protection of intellectual property, problems related to security and professional } \\
\text { intrusion, socio-political instability, commercial barriers, etc. }\end{array}$ \\
\hline - $\quad$ Scope and Requirements & Conflicting requirements, badly-defined project, inadequate or incorrect requirements, etc. \\
\hline - $\quad$ Planning and Control & $\begin{array}{l}\text { Changing and growing objectives and requirements, low visibility of the project, deficient } \\
\text { audit, quality and control. Deficient change management, deficient project leadership, } \\
\text { deficient project planning, etc. }\end{array}$ \\
\hline - $\quad$ Execution & $\begin{array}{l}\text { Unsuitable disaster recovery operations, incompatible development choice, logistic } \\
\text { complications, non-compliance with the previously specified methodologies, technological } \\
\text { discontinuity, etc. }\end{array}$ \\
\hline & Bahli and Rivard $(2002 ; 2005)$ \\
\hline - $\quad$ Asset specificity & $\begin{array}{l}\text { If the client uses highly specific assets of the provider, it is hard to believe that the former } \\
\text { can easily switch to another provider. }\end{array}$ \\
\hline - $\quad$ Small number of providers & $\begin{array}{l}\text { If few alternative providers exist, the client is in a difficult position when it comes to } \\
\text { negotiating contracts. }\end{array}$ \\
\hline - $\quad$ Uncertainty & $\begin{array}{l}\text { Uncertainty makes it inevitable for outsourcing contracts to be incomplete, which is why } \\
\text { they need to be renegotiated when contingencies arise. }\end{array}$ \\
\hline - $\quad$ Relationship & $\begin{array}{l}\text { Interdependences between outsourced services and internal ones or between several } \\
\text { outsourced services are likely to cause problems and mismatches between them. }\end{array}$ \\
\hline - $\quad$ Measurement problems & $\begin{array}{l}\text { The difficulty to assess the contribution made by an external provider may generate } \\
\text { disagreements in the quality/price ratio of the services received. }\end{array}$ \\
\hline - $\quad$ Experience in IT Operation & $\begin{array}{l}\text { If there is lack of experience on the part of the client, the latter can lose control over costs. If } \\
\text { the lack of experience corresponds to the provider, the latter is likely to overestimate its } \\
\text { capabilities and thus be unable to meet the needs of the former. }\end{array}$ \\
\hline - $\quad$ Experience in outsourcing & $\begin{array}{l}\text { If there is lack of experience on the part of the client, the latter may negotiate badly before } \\
\text { an advantaged provider. If it is the provider that lacks experience, lawsuits and disputes are } \\
\text { likely to arise in relation to contract characteristics. }\end{array}$ \\
\hline & Earl (1996) \\
\hline - $\quad$ Deficient management & $\begin{array}{l}\text { The client company must be able to guide the provider so as to reduce the risks inherent in } \\
\text { outsourcing. }\end{array}$ \\
\hline Unskilled staff & It refers to the provider's staff. \\
\hline - Uncertainty in businesses & $\begin{array}{l}\text { If the company is outsourcing for cost control or reduction purposes, it has to be assumed } \\
\text { that its future management and needs are clear. And this is not always the case. }\end{array}$ \\
\hline $\begin{array}{l}\text { Outdated technological } \\
\text { knowledge }\end{array}$ & It refers to providers' knowledge. \\
\hline - $\quad$ Endemic uncertainty & $\begin{array}{l}\text { IT-related operations are inherently surrounded by uncertainty: Users cannot specify their } \\
\text { needs; new technology is risky; business requirements keep changing; and the } \\
\text { implementation is usually full of surprises. }\end{array}$ \\
\hline - $\quad$ Hidden costs & $\begin{array}{l}\text { These costs comprise those related to contract management and the ones involved in the } \\
\text { transition towards outsourcing. }\end{array}$ \\
\hline - $\quad$ Lack of organizational learning & $\begin{array}{l}\text { A large proportion of learning about IT capabilities is experimental; in other words, people } \\
\text { learn what they can do with ITs by using them. This learning is lost when outsourcing takes } \\
\text { place. }\end{array}$ \\
\hline - Loss of innovative capacity & $\begin{array}{l}\text { If the company outsources and, as a result, has fewer IT staff, it may lose its innovation } \\
\text { capacity in that area. }\end{array}$ \\
\hline - Dangers of the eternal triangle & $\begin{array}{l}\text { It refers to users, to IT staff and to those acting as intermediaries between them, who are } \\
\text { present in many companies. }\end{array}$ \\
\hline - $\quad$ Technological indivisibility & $\begin{array}{l}\text { Many of the ITs are not indivisible and problems are likely to arise when it comes to } \\
\text { identifying the responsibility of the client or the provider or that of the different providers } \\
\text { with whom outsourcing agreements have been reached. }\end{array}$ \\
\hline - $\quad$ Diffuse approach & $\begin{array}{l}\text { Outsourcing very often focuses on the IT supply rather than on clients' demands, on the } \\
\text { 'how' of ITs rather on the 'what.' }\end{array}$ \\
\hline & Fan, Suo and Feng (2012) \\
\hline - $\quad$ Technological indivisibility & $\begin{array}{l}\text { Since many IT projects are not divisible, trying to have them managed by different providers } \\
\text { may turn out to be problematic. }\end{array}$ \\
\hline
\end{tabular}




\begin{tabular}{|c|c|}
\hline Possible weak management & A weak management is likely to increase costs and lead to conflicts and dissatisfaction. \\
\hline - $\quad$ Cultural fit & $\begin{array}{l}\text { A deficient cultural fit between client and provider may damage the outsourcing } \\
\text { relationships and result in client-provider conflicts. }\end{array}$ \\
\hline Requirement instability & Clients' requirements may change in the course of the IT outsourcing operation. \\
\hline $\begin{array}{l}\text { - } \begin{array}{l}\text { Coordination between client and } \\
\text { seller }\end{array} \\
\end{array}$ & $\begin{array}{l}\text { Effective coordination between client and seller will most probably favor fruitful } \\
\text { cooperation in the outsourcing process. }\end{array}$ \\
\hline - $\quad$ Reliability of the sellers chosen & Non-responsible providers may influence the scheduling of outsourcing operations. \\
\hline Uncertain legal context & An uncertain legal environment is also likely to affect the outsourcing operation. \\
\hline \multirow[t]{2}{*}{ - Technological complexity } & $\begin{array}{l}\text { Technological complexity may largely determine the outsourcing schedule as well as the } \\
\text { quality of the tasks performed. }\end{array}$ \\
\hline & Gandhi, Gorod and Sauser (2012) \\
\hline - $\quad$ Related to scheduling & Uncertainty about whether or not the outsourcing project will be finished at the agreed time \\
\hline Technical & Uncertainty about whether or not technology will be able to bring the expected benefits \\
\hline - $\quad$ Financial & $\begin{array}{l}\text { Uncertainty about whether or not the outsourced project will be completed with the } \\
\text { established budget }\end{array}$ \\
\hline Seller & Uncertainty about whether or not an inadequate provider can impact on the project outcomes \\
\hline Culture & Possible cultural clashes between client and provider \\
\hline Reputation & $\begin{array}{l}\text { Outsourcing is likely to damage the client's reputation especially due to the loss of jobs that } \\
\text { this process may entail. }\end{array}$ \\
\hline - Intellectual Property & $\begin{array}{l}\text { The risk that the provider might use or share the client's ideas with others, thus causing the } \\
\text { loss of a part of its market by the said client }\end{array}$ \\
\hline - $\quad$ Flexibility & $\begin{array}{l}\text { Outsourcing is likely to generate flexibility but it can also result in the client's loss of control } \\
\text { over the outsourced functions, which in turn will affect their flexibility. }\end{array}$ \\
\hline - $\quad$ Compliance & $\begin{array}{l}\text { Compliance with local laws may be complicated when client and provider do not come from } \\
\text { the same country. }\end{array}$ \\
\hline \multirow[t]{2}{*}{ - $\quad$ Quality } & Inability to meet clients' demands and requirements \\
\hline & Grover and Teng (1993) \\
\hline - $\quad$ Risk of obsolescence & The provider may neglect the updating of the ITs that it uses to deliver its services. \\
\hline - Loss of flexibility & $\begin{array}{l}\text { The client's needs may be neglected, there may be delays in relation to task compliance, and } \\
\text { flexibility is likely to be lost. }\end{array}$ \\
\hline - $\quad$ Loss of control & $\begin{array}{l}\text { The real control over software quality and planning compliance is reduced, insofar as the } \\
\text { client cannot monitor the staff in charge of implementing projects. }\end{array}$ \\
\hline Staff security & The IS internal staff may be displaced. \\
\hline $\begin{array}{l}\text { - Cost associated with negotiating } \\
\text { and enforcing the contract }\end{array}$ & $\begin{array}{l}\text { A lot of time and effort is required to ensure coordination and communication with the } \\
\text { provider. }\end{array}$ \\
\hline - Data or system security & $\begin{array}{l}\text { Because the provider can offer services similar to those offered by direct competitors, and } \\
\text { clients' data are handled by the provider. }\end{array}$ \\
\hline \multirow[t]{2}{*}{$\begin{array}{l}\text { - } \quad \begin{array}{l}\text { Not caring for the client's } \\
\text { interest }\end{array} \\
\end{array}$} & Providers try to maximize their profit, which can sometimes go against the clients' interests. \\
\hline & Harland, Knight, Lamming and Walker (2005) \\
\hline - $\quad$ Outsourcing basic activities & $\begin{array}{l}\text { Competitive advantages are lost when the company cannot distinguish basic activities from } \\
\text { non-basic ones. }\end{array}$ \\
\hline - $\quad$ Difficulty to insource & Outsourcing may be irreversible, since internal competences and skills have been lost. \\
\hline $\begin{array}{l}\text { Lack of knowledge and } \\
\text { competences to manage } \\
\text { relationships }\end{array}$ & $\begin{array}{l}\text { There must be a solid agreement about service levels (Service Level Agreement) in order to } \\
\text { know what is going to be outsourced, how to measure it, how to assess it, etc. }\end{array}$ \\
\hline \multirow[t]{2}{*}{$\begin{array}{l}\text { - Lack of knowledge to design } \\
\text { service level agreements }\end{array}$} & $\begin{array}{l}\text { It is difficult to design these Service Level Agreements if one is not knowledgeable in areas } \\
\text { such as negotiation, IT, labor needs, price, etc. }\end{array}$ \\
\hline & Nakatsu and Iacovou (2009) \\
\hline $\begin{array}{l}\text { - } \quad \text { Related to the IS human } \\
\text { resources }\end{array}$ & $\begin{array}{l}\text { Staff turnover, lack of communication, lack of technical knowledge, lack of motivation, } \\
\text { conflicts, etc. }\end{array}$ \\
\hline - $\quad$ Organizational Environment & $\begin{array}{l}\text { Lack of support from the top management, inadequate organizational policies, changes in } \\
\text { organizational priorities, etc. }\end{array}$ \\
\hline - $\quad$ Requirements & $\begin{array}{l}\text { Failing to explain the initial requirements properly, or constantly changing the requirements } \\
\text { and leaving them unclear }\end{array}$ \\
\hline - $\quad$ Planning and control & $\begin{array}{l}\text { Lack of know how in project management, agenda planning and deficient budgets, deficient } \\
\text { change monitoring, problems resulting from the failure to consider all costs }\end{array}$ \\
\hline - $\quad$ Related to users & $\begin{array}{l}\text { Lack of involvement by users, failure to obtain their commitment, wrong information about } \\
\text { users' expectations, conflicts between user departments }\end{array}$ \\
\hline - $\quad$ Project complexity & $\begin{array}{l}\text { Integration difficulties, a large number of connections with other systems, automated } \\
\text { processes are complex, inadequate understanding of new technology }\end{array}$ \\
\hline
\end{tabular}




\begin{tabular}{|c|c|}
\hline & Palvia (1995) \\
\hline - $\quad$ Coordination costs & $\begin{array}{l}\text { The costs associated with coordination and communication between client and provider are } \\
\text { likely to be considerable. }\end{array}$ \\
\hline - $\quad$ Flexibility and control & $\begin{array}{l}\text { Neither ITs nor the outsourced systems are monitored, which reduces flexibility for the } \\
\text { client. This is the main reason for the retention of strategic systems. }\end{array}$ \\
\hline \multirow[t]{2}{*}{ - $\quad$ Staff problems } & $\begin{array}{l}\text { Derived from low morale, uncertainty, anxiety and the rumors which can be common among } \\
\text { the client's IT staff with regard to possible lay-offs or modifications in their work contracts. }\end{array}$ \\
\hline & Sullivan and Ngwenyama (2005) Ngwenyama and Sullivan (2007) \\
\hline - Client's Lack of experience & $\begin{array}{l}\text { The client does not have enough experience in the function or process to be outsourced, or in } \\
\text { the technology or in the outsourcing contracts. }\end{array}$ \\
\hline $\begin{array}{l}\text { Provider's opportunistic } \\
\text { behavior }\end{array}$ & $\begin{array}{l}\text { The provider may show an unethical behavior, for example, generating high change costs or } \\
\text { binding the client with a very specific technology. }\end{array}$ \\
\hline - $\quad$ Provider's lack of experience & $\begin{array}{l}\text { The same as the client, the provider may not have enough experience in the function or } \\
\text { process to be outsourced, or in the technology or in the outsourcing contracts. }\end{array}$ \\
\hline - $\quad$ Seller's financial responsibility & $\begin{array}{l}\text { The seller is likely to look for other customers that generate more profits, or it may also want } \\
\text { to terminate the contract due to financial problems. }\end{array}$ \\
\hline - $\quad$ Monitoring of the seller's results & $\begin{array}{l}\text { The inability to adequately specify the results expected from the provider may result in } \\
\text { increasingly bad services. }\end{array}$ \\
\hline - $\quad$ Contract length & $\begin{array}{l}\text { This length can have an influence on the loss of experienced staff due to turnover issues; it } \\
\text { may generate technological discontinuity in the event that the technology which forms part } \\
\text { of the contract should become obsolete, etc. }\end{array}$ \\
\hline \multirow[t]{2}{*}{$\begin{array}{l}\text { - Loss of basic competences and } \\
\text { information }\end{array}$} & It refers to the possible loss of competences or key staff. \\
\hline & Willcocks, Lacity and Kern (1999) \\
\hline $\begin{array}{l}\text { - Treating ITs as indistinct goods } \\
\text { to be outsourced }\end{array}$ & ITs are not the same as other company services when it comes to outsourcing. \\
\hline - Incomplete contract & An incomplete contract generates a surcharge for any non-included service. \\
\hline $\begin{array}{l}\text { - Lack of active management with } \\
\text { regard to the contract provider } \\
\text { and the subsequent relationships }\end{array}$ & It is necessary to establish communication and control mechanisms with regard to providers. \\
\hline $\begin{array}{l}\text { - Failure to build and retain the } \\
\text { suitable knowledge and skills } \\
\text { internally }\end{array}$ & $\begin{array}{l}\text { It is not possible to outsource everything, decapitalizing the company of all its IT } \\
\text { knowledge. }\end{array}$ \\
\hline $\begin{array}{l}\text { - Power asymmetry in favor of the } \\
\text { provider }\end{array}$ & $\begin{array}{l}\text { The provider has more experience in dealing with clients (because it has many of them) than } \\
\text { the client has in dealing with IT providers. }\end{array}$ \\
\hline $\begin{array}{l}\text { Difficulties to build and adapt } \\
\text { agreements before the rapid } \\
\text { technological and business- } \\
\text { related changes }\end{array}$ & $\begin{array}{l}\text { If the contract does not refer to the updating of services as technological changes take place } \\
\text { in the market or modifications are introduced in the actual client's business, those changes } \\
\text { will not be taken into account in the outsourced service. }\end{array}$ \\
\hline $\begin{array}{l}\text { - Lack of maturity and experience } \\
\text { in contracting to manage 'total' } \\
\text { outsourcing contracts }\end{array}$ & The client is completely in the provider's hands if it outsources its whole IT service. \\
\hline - $\quad$ Short-term approach & $\begin{array}{l}\text { Some firms decide to outsource thinking exclusively about the short term, about removing } \\
\text { fixed costs, and seeking to achieve an economic injection rather than to improve their IT } \\
\text { assets with the aim of achieving competitive advantages. }\end{array}$ \\
\hline $\begin{array}{l}\text { - Unrealistic expectations with } \\
\text { multiple outsourcing goals }\end{array}$ & $\begin{array}{l}\text { Outsourcing is not the panacea for every problem in the IT area; companies need to have } \\
\text { clear goals, whether it is improving quality or cutting costs, reducing complexity, etc. }\end{array}$ \\
\hline $\begin{array}{l}\text { - Deficient contracting for new } \\
\text { technology development }\end{array}$ & Lack of knowledge about contract negotiation and management \\
\hline
\end{tabular}


Table 3: Variables' Measures and Reliability

\begin{tabular}{cccc}
\hline Construct & Source & Measure & $\begin{array}{c}\text { Reliability } \\
(\text { Cronbach's } \alpha)\end{array}$ \\
\hline IS Outsourcing Reasons & $\begin{array}{c}\text { Literature review, 2001 } \\
\text { questionnaire, 2006 } \\
\text { questionnaire and self- } \\
\text { elaboration }\end{array}$ & $\begin{array}{c}10 \text { items measured with a 1- } \\
\text { to-7 Likert scale }\end{array}$ & 0.766 \\
\hline IS Outsourcing Risks & Idem & $\begin{array}{c}11 \text { items measured with a 1- } \\
\text { to-7 Likert scale }\end{array}$ & 0.841 \\
\hline
\end{tabular}

Table 4: Study technical specifications

\begin{tabular}{cccc}
\hline & Year 2001 & Year 2006 & Year 2013 \\
\hline Scope & Spain & Spain & Spain \\
Population & 4,416 largest Spanish & 4,107 largest Spanish & 4,955 largest Spanish \\
& companies & companies & companies \\
Sampling Size & 357 valid responses & 329 valid responses & 398 valid responses \\
Sampling Error & $(8.08 \%)$ & $(8.02 \%)$ & $(8.03 \%)$ \\
Survey Date & $5 \%$ & $5 \%$ & $4.7 \%$ \\
\hline
\end{tabular}

Table 5: Companies' overall characteristics

\begin{tabular}{|c|c|c|c|c|c|c|c|}
\hline & & 2001 & & 2000 & & 2013 & \\
\hline & & $\mathrm{N}$ & $\%$ & $\mathrm{~N}$ & $\%$ & $\mathrm{~N}$ & $\%$ \\
\hline & Yes & 51 & 14.3 & 54 & 16.4 & 54 & 13.6 \\
\hline Outsourcing & No & 306 & 85.7 & 275 & 83.6 & 344 & 86.4 \\
\hline & Below the Average & 175 & 49.0 & 165 & 50.2 & 192 & 48.2 \\
\hline Degree of Outsourcing & Above the Average & 182 & 51.0 & 164 & 49.8 & 206 & 51.8 \\
\hline & $0-50$ & 22 & 6.2 & 28 & 8.5 & 43 & 10.8 \\
\hline & $51-500$ & 202 & 56.6 & 218 & 66.2 & 233 & 58.5 \\
\hline Number of Workers & More than 500 & 132 & 36.9 & 76 & 23.1 & 112 & 28.2 \\
\hline & Lost & 1 & 0.3 & 7 & 2.1 & 10 & 2.5 \\
\hline & Up to 30 & 36 & 10.1 & 31 & 9.4 & 9 & 2.3 \\
\hline & More than 30 and up to 60 & 227 & 63.6 & 146 & 44.3 & 170 & 42.7 \\
\hline $\begin{array}{l}\text { Sales } \\
\text { (million }\end{array}$ & More than 60 and up to 300 & 38 & 10.6 & 129 & 39.2 & 149 & 37.4 \\
\hline (millions of €) & More than 300 & 55 & 15.4 & 16 & 4.9 & 60 & 15.1 \\
\hline & Lost & 1 & 0.3 & 7 & 2.1 & 10 & 2.5 \\
\hline & Industry & 210 & 58.8 & 189 & 57.4 & 178 & 44.7 \\
\hline & Services & 118 & 33.1 & 102 & 31.0 & 158 & 39.7 \\
\hline Sector & ICT-Intensive Services & 29 & 8.1 & 38 & 11.6 & 52 & 13.1 \\
\hline & Lost & 0 & 0 & 0 & 0 & 10 & 2.5 \\
\hline & 0-10 Employees & 240 & 67.2 & 250 & 76.0 & 270 & 67.8 \\
\hline & 11-100 Employees & 96 & 26.9 & 66 & 20.1 & 98 & 24.6 \\
\hline IS Staff & More than 100 Employees & 5 & 1.4 & 6 & 1.8 & 14 & 3.5 \\
\hline & Lost & 16 & 4.5 & 7 & 2.1 & 16 & 4.0 \\
\hline & $0-4$ & 133 & 37.2 & 138 & 41.9 & 198 & 49.7 \\
\hline Budget Percentage & $5-10$ & 61 & 17.1 & 56 & 17.0 & 58 & 14.6 \\
\hline allocated to IS & More than 10 & 18 & 5.1 & 13 & 4 & 16 & 4.0 \\
\hline & Lost & 145 & 40.6 & 122 & 37.1 & 126 & 31.7 \\
\hline
\end{tabular}


Table 6: Outsourcing Reasons

Not Important at all 122345667 Very Important

\begin{tabular}{|l|c|c|c|}
\hline & Mean & Median & Mode \\
\hline Focusing on Strategic Issues & 5.74 & 6 & 7 \\
Increasing Dept. Flexibility & 5.25 & 6 & 7 \\
Improving Quality & 4.87 & 5 & 7 \\
Getting Rid of Routine Tasks & 4.85 & 5 & 6 \\
Facilitating Access to Technolog. & 4.76 & 5 & 6 \\
Reducing Risk of Obsolescence & 4.73 & 5 & 6 \\
Saving Staff Costs & 4.26 & 4 & 4 \\
Saving Technology Costs & 4.23 & 4 & 4 \\
Having Alternatives to Internal IS & 4.22 & 4 & 5 \\
Joining the Fashion & 1.80 & 1 & 1 \\
\hline
\end{tabular}

Table 7: Total Variance Explained and Rotated Factor Matrix from the Reasons Factor Analysis

\begin{tabular}{|c|c|c|c|c|c|c|c|c|c|c|}
\hline \multicolumn{7}{|c|}{ Total Variance Explained } & \multicolumn{4}{|c|}{ Rotated Factor Matrix } \\
\hline & \multicolumn{3}{|c|}{ Initial Eigenvalues } & \multicolumn{3}{|c|}{ Rotation Sum of Squared Loadings } & \multirow[t]{2}{*}{ Variable } & \multicolumn{3}{|c|}{ Factor } \\
\hline Factor & Total & $\begin{array}{l}\text { Percent. of } \\
\text { Variance }\end{array}$ & $\begin{array}{c}\text { Cumulative } \\
\%\end{array}$ & Total & $\begin{array}{l}\text { Percent. } \\
\text { of } \\
\text { Variance }\end{array}$ & $\begin{array}{c}\text { Cumulative } \\
\%\end{array}$ & & 1 & 2 & 3 \\
\hline 1 & 3.306 & 33.064 & 33.064 & 3.306 & 33.064 & 33.064 & Focusing on Strategic Issues & 0.796 & & \\
\hline 2 & 1.603 & 16.034 & 49.098 & 1.603 & 16.034 & 49.098 & Increasing Dept. Flexibility & 0.639 & & \\
\hline 3 & 1.095 & 10.949 & 60.047 & 1.095 & 10.949 & 60.047 & Improving Quality & 0.667 & & \\
\hline 4 & .833 & 8.330 & 68.377 & & & & Getting Rid of Routine Tasks & 0.768 & & \\
\hline 5 & .725 & 7.251 & 75.628 & & & & Facilitating Access to Technol. & & 0.626 & \\
\hline 6 & .673 & 6.726 & 82.354 & & & & Reducing Risk of Obsolescence & & 0.600 & \\
\hline 7 & .581 & 5.808 & 88.162 & & & & Saving Staff Costs & & & 0.881 \\
\hline 8 & .467 & 4.667 & 92.828 & & & & Saving Technology Costs & & & 0.826 \\
\hline 9 & .403 & 4.034 & 96.862 & & & & Having Alternativ.to internal IS & & 0.769 & \\
\hline 10 & .314 & 3.138 & 100.000 & & & & Joining the Fashion & & 0.533 & \\
\hline
\end{tabular}

Table 8: Mean Equality Test for Outsourcing Reasons according to the different Characteristics of Firms

\begin{tabular}{|c|c|c|c|c|c|c|}
\hline & & & \multicolumn{2}{|c|}{ Levene } & \multirow[b]{2}{*}{ (Student's) $\mathrm{T}$} & \multirow[b]{2}{*}{ Sign. } \\
\hline & Sales & Means & $\mathrm{F}$ & Sign. & & \\
\hline Factor 1: Strategic Reasons & $\begin{array}{l}\text { Up to } 67 \\
\text { More than } 67\end{array}$ & $\begin{array}{l}-0.147 \\
0.175\end{array}$ & 3.094 & 0.079 & -3.107 & 0.002 \\
\hline Factor 2: Technological Reasons & $\begin{array}{l}\text { Up to } 67 \\
\text { More than } 67\end{array}$ & $\begin{array}{l}0.058 \\
-0.025\end{array}$ & 0.015 & 0.902 & 0.803 & 0.423 \\
\hline \multirow[t]{2}{*}{ Factor 3: Economic Reasons } & $\begin{array}{l}\text { Up to } 67 \\
\text { More than } 67\end{array}$ & $\begin{array}{c}0.188 \\
-0.180\end{array}$ & 3.888 & 0.049 & $13195^{*}$ & 0.001 \\
\hline & Number of Workers & & & & & \\
\hline Factor 1: Strategic Reasons & $\begin{array}{l}\text { Up to } 230 \\
\text { More than } 230\end{array}$ & $\begin{array}{l}-0.201 \\
0.234 \\
\end{array}$ & 2.576 & 0.109 & -4.246 & 0.000 \\
\hline Factor 2: Technological Reasons & $\begin{array}{l}\text { Up to } 230 \\
\text { More than } 230\end{array}$ & $\begin{array}{l}0.015 \\
0.017\end{array}$ & 0.010 & 0.921 & -0.016 & 0.987 \\
\hline \multirow[t]{2}{*}{ Factor 3: Economic Reasons } & $\begin{array}{l}\text { Up to } 230 \\
\text { More than } 230\end{array}$ & $\begin{array}{l}0.073 \\
-0.068\end{array}$ & 3.630 & 0.058 & 1.356 & 0.176 \\
\hline & IS Staff & & & & & \\
\hline Factor 1: Strategic Reasons & $\begin{array}{l}\text { Below Average } \\
\text { Above Average }\end{array}$ & $\begin{array}{l}-0.013 \\
0.051\end{array}$ & 3.846 & 0.051 & -0.649 & 0.516 \\
\hline Factor 2: Technological Reasons & $\begin{array}{l}\text { Below Average } \\
\text { Above Average }\end{array}$ & $\begin{array}{r}0.037 \\
-0.042 \\
\end{array}$ & 2.308 & 0.130 & 0.747 & 0.546 \\
\hline \multirow[t]{2}{*}{ Factor 3: Economic Reasons } & $\begin{array}{l}\text { Below Average } \\
\text { Above Average }\end{array}$ & $\begin{array}{c}0.118 \\
-0.125\end{array}$ & 0.426 & 0.514 & 2.319 & 0.021 \\
\hline & $\begin{array}{l}\text { Degree of } \\
\text { Outsourcing }\end{array}$ & & & & & \\
\hline Factor 1: Strategic Reasons & $\begin{array}{l}\text { Below Average } \\
\text { Above Average }\end{array}$ & $\begin{array}{c}-0.323 \\
0.290 \\
\end{array}$ & 21.817 & 0.000 & $22512 *$ & 0.000 \\
\hline Factor 2: Technological Reasons & $\begin{array}{l}\text { Below Average } \\
\text { Above Average }\end{array}$ & $\begin{array}{l}-0.020 \\
0.018\end{array}$ & 0.461 & 0.498 & -0.382 & 0.703 \\
\hline Factor 3: Economic Reasons & $\begin{array}{l}\text { Below Average } \\
\text { Above Average }\end{array}$ & $\begin{array}{l}-0.128 \\
0.115\end{array}$ & 0.056 & 0.814 & -2.366 & 0.018 \\
\hline
\end{tabular}

*Mann-Whitney's U statistic 
Table 9: Outsourcing Risks

Not Important at all 1123345667 Very Important

\begin{tabular}{|l|c|c|c|}
\hline & Mean & Median & Mode \\
\hline Staff Qualification & 5.49 & 6 & 6 \\
Excessive Dependence & 5.37 & 6 & 6 \\
Lack of Compliance & 5.09 & 5 & 6 \\
Loss of Knowledge & 4.39 & 4 & 6 \\
Provider's Inability to Adapt & 4.12 & 4 & 5 \\
Hidden Costs & 4.07 & 4 & 4 \\
Security Problems & 4.06 & 4 & 5 \\
Unclear C/B Relationship & 3.87 & 4 & 4 \\
Irreversibility of the Decision & 3.53 & 4 & 4 \\
Possible Staff Opposition & 3.35 & 3 & 2 \\
Staff Problems & 3.05 & 3 & 2 \\
\hline
\end{tabular}

Tabla 10: Total Variance Explained and Rotated Factor Matrix from the Risks Factor Analysis

\begin{tabular}{|c|c|c|c|c|c|c|c|c|c|}
\hline \multirow[b]{3}{*}{ Factor } & \multicolumn{6}{|c|}{ Total Variance Explained } & \multicolumn{3}{|c|}{ Rotated Factor Matrix } \\
\hline & \multicolumn{3}{|c|}{ Initial Eigenvalues } & \multicolumn{3}{|c|}{ Rotation Sum of Squared Loadings } & \multirow[t]{2}{*}{ Variable } & \multicolumn{2}{|c|}{ Factor } \\
\hline & Total & $\begin{array}{l}\text { Percent. } \\
\text { of } \\
\text { Variance }\end{array}$ & $\begin{array}{c}\text { Cumulative } \\
\%\end{array}$ & Total & $\begin{array}{c}\text { Percent. } \\
\text { of } \\
\text { Variance }\end{array}$ & $\begin{array}{c}\text { Cumulative } \\
\%\end{array}$ & & 1 & 2 \\
\hline 1 & 4.275 & 38.859 & 38.859 & & & & Staff Qualification & & 0.607 \\
\hline 2 & 1.214 & 11.036 & 49.896 & 2.907 & 26.423 & 26.423 & Excessive Dependence & & 0.572 \\
\hline 3 & .953 & 8.661 & 58.556 & & & & Lack of Compliance & & 0.785 \\
\hline 4 & .823 & 7.481 & 66.037 & 2.582 & 23.473 & 49.896 & Provider's Inability to Adapt & & 0.624 \\
\hline 5 & .775 & 7.041 & 73.078 & & & & Loss of Knowledge & 0.499 & \\
\hline 6 & .732 & 6.657 & 79.735 & & & & Unclear C/B Relationship & 0.500 & \\
\hline 7 & .668 & 6.077 & 85.812 & & & & Hidden Costs & & 0.538 \\
\hline 8 & .561 & 5.101 & 90.913 & & & & Irreversibility of the Decision & 0.648 & \\
\hline 9 & .375 & 3.410 & 94.323 & & & & Possible Staff Opposition & 0.838 & \\
\hline 10 & .335 & 3.050 & 97.373 & & & & Security Problems & 0.515 & \\
\hline 11 & .289 & 2.627 & 100.000 & & & & Staff Problems & 0.839 & \\
\hline
\end{tabular}

Table 11: Outsourcing Reasons and Risks (2013-2006-2001)

\begin{tabular}{|c|c|c|c|c|c|c|c|}
\hline \multicolumn{4}{|l|}{ Reasons Ranking (2013-2006-2001) } & \multicolumn{4}{|c|}{ Risks Ranking (2013-2006-2001) } \\
\hline Focusing on Strategic Issues & $1^{\text {st }}$ & $1^{\text {st }}$ & $1^{\mathrm{st}}$ & Staff Qualification & $1^{\text {st }}$ & $1^{\mathrm{st}}$ & $3^{\text {rd }}$ \\
\hline Increasing Dept. Flexibility & $2^{\text {nd }}$ & $2^{\text {nd }}$ & $2^{\text {nd }}$ & Excessive Dependence & $2^{\text {nd }}$ & $3^{\text {rd }}$ & $1^{\text {st }}$ \\
\hline Improving Quality & $3^{\text {rd }}$ & $3^{\text {rd }}$ & $3^{\text {rd }}$ & Lack of Compliance & $3^{\text {rd }}$ & $2^{\text {nd }}$ & $4^{\text {th }}$ \\
\hline Getting Rid of Routine Tasks & $4^{\text {th }}$ & $4^{\text {th }}$ & $4^{\text {th }}$ & Loss of Knowledge & $4^{\text {th }}$ & $4^{\text {th }}$ & $2^{\text {nd }}$ \\
\hline Facilitating Access to Technol. & $5^{\text {th }}$ & $5^{\text {th }}$ & $6^{\text {th }}$ & Provider's Inability to Adapt & $5^{\text {th }}$ & $5^{\text {th }}$ & $10^{\text {th }}$ \\
\hline Reducing Risk of Obsolescence & $6^{\text {th }}$ & $6^{\text {th }}$ & - & Hidden Costs & $6^{\text {th }}$ & $6^{\text {th }}$ & $6^{\text {th }}$ \\
\hline Saving Staff Costs & $7^{\text {th }}$ & $7^{\text {th }}$ & $5^{\text {th }}$ & Security Problems & $7^{\text {th }}$ & $8^{\text {th }}$ & $7^{\text {th }}$ \\
\hline Saving Technology Costs & $8^{\text {th }}$ & $9^{\text {th }}$ & $7^{\text {th }}$ & Unclear C/B Relationship & $8^{\text {th }}$ & $7^{\text {th }}$ & $5^{\text {th }}$ \\
\hline Having Alternativ. to internal IS & $9^{\text {th }}$ & $8^{\text {th }}$ & $8^{\text {th }}$ & Irreversibility of the Decision & $9^{\text {th }}$ & $9^{\text {th }}$ & $8^{\text {th }}$ \\
\hline Joining the Fashion & $10^{\text {th }}$ & $10^{\text {th }}$ & $9^{\text {th }}$ & Possible Staff Opposition & $10^{\text {th }}$ & $11^{\text {th }}$ & $9^{\text {th }}$ \\
\hline & & & & Staff Problems & $11^{\text {th }}$ & $10^{\text {th }}$ & - \\
\hline
\end{tabular}

